\title{
UDC 215+159.9
}

\author{
O. I. PREDKO ${ }^{1^{*}}$ \\ ${ }^{1 *}$ Taras Shevchenko National University of Kyiv (Kyiv, Ukraine), e-mail olenapredko@knu.ua, ORCID 0000-0002-9908-7788
}

\section{RELIGIOUS FAITH: EXISTENTIAL-ANTHROPOLOGICAL MEANINGS}

Purpose. The aim of this article is to analyse the essential features of religious faith as an existentialpersonalistic model of the formation of a person, his worldview orientations and activities. This requires a consistent solution of the following tasks: a) to focus on different approaches to understanding the phenomenon of "religious faith" (as a problem of principled openness, incompleteness of a person; as the problem of "I-Other" relations; as a problem of synthesis of the human and the divine, etc.); b) to reveal the spiritual potential of religious faith, its capabilities in boundary situations. Theoretical basis. The author thinks that the interpretation of religious faith as confidence in the invisible is unsatisfactory, one-sided and superficial. Religious faith is the existential, due to which a person overcomes the contradictions between finiteness and infinity. It is the construct of the human spirit, which makes its way into the transcendental realm. In this context, religious faith is a kind of criterion for the "growth" of the "human" in human, the criterion of his spirituality and humanity. Religious faith, being an integral part of human existence, gives it irrational dimensions, makes the possibility of impossible. The existential potential of religious faith serves as the "fulcrum" of a person, thanks to which he self-actualizes, self-fulfills and forms a certain worldview model. Originality. The author has proved that religious faith, which is the projective model of a person, turns out to be one of the possible ways to solve its existential problems, as it concerns not only the nature of the essential characteristics, the properties of the Divine itself but also the ultimate foundations of person in all the uniqueness and specificity of his being. Conclusions. Religious faith, acting as a factor in human activity, builds his value-worldview model of the world. Faith deals with the "ultimate" problems of human existence since it is of exceptional importance in solving life-meaning issues of human existence. The existential experience of the believer acquires the status of an event that opens up a field of new possibilities, a new spiritual experience. The accumulative effect of such experience forms the spiritual and value priorities of human existence, sets certain coordinates of his vital activity, due to which he self-determines, being in dialogue with the Absolute. Religious faith, unfolding as a permanent process of "search and finding" opens the "code" of transcendence, a new level of relations of the Human and Divine. Love

Keywords: religious faith; existential-faith experience; dialogue; spirituality; boundary situation; Faith-Hope-

\section{Introduction}

In today's dynamic, globalized world, which is constantly changing and affected by modification tendencies, a person is forced to look for new ways to counter the destructive tendencies, to actualize civilizational challenges for the preservation of everything purely human. Therefore, it is understandable why today the priority questions are about the meaning and goals of human life, worldview values and perspective opportunities for the existence of all mankind. In this context, contemporary civilization is increasingly striving for ways of preserving the person based on the new spiritual foundations of development, on those existential issues that would become one of the core factors of his value-semantic sphere of being. Such a phenomenon is religious faith. Person, including religious faith as a construct and a unique imperative of his identity, joins the field of transcendental, the possibility of being spiritually enriched and secure from the state of disappointment, uncertainty, and depression. The growing interest in the phenomenon of religious faith in modern theoretical thought is due to the emergence of interreligious contradictions, an attempt to preserve "their" religious identity. Moreover, these processes often contribute to the emergence of new social risks and religious conflicts. We are talking about the problem of the Other, of his religion and faith. As a result, an appropriate way of existence in the surround- 
ing world requires a certain religious representation. For the most part, the field for the deployment of such representations is faith as communication, dialogue and a construct of mutual understanding. In recent years, scientists have been paying attention to its psychotherapeutic function. In particular, Viktor Moskalets and Alla Oliinyk (2018) consider religious faith as a factor of "mitigation" of various life situations. Empirical studies of David C. Dollahite, Loren D. Marks, Kate P. Babcock, Betsy H. Barrow and Andrew H. Rose (2019) emphasize that those families in which religious faith is traditionally passed between generations have a much better family microclimate. However, among researchers, there is no agreement on the nature of the phenomenon of religious faith, its understanding as an existential-anthropological construct, in the semantic field of which this phenomenon would be considered from the point of meaningcreation functions, where not only the issues of how to live or how to save life are raised, but also why you need to live.

\section{Purpose}

The purpose of the article is to clarify the essence of religious faith as an existential construct of forming a holistic personality, its ideological attitudes, and activities. This requires a consistent solution of the following tasks: a) to focus on different approaches to understanding the phenomenon of "religious faith" (as a problem of principled openness, the incompleteness of a person; as the problem of "I-Other" relations; as a problem of synthesis of the human and the divine, etc.); b) to reveal the spiritual potential of religious faith, its capabilities in boundary situations.

\section{Statement of basic materials}

For a long time, the phenomenon of religious faith was directly associated with its biblical definition. However, in this regard only one aspect of the consideration of this unique phenomenon is visible. Undoubtedly, the content of religious faith is more universal. In the Holy Scripture, there is a definition of faith: "Now faith is confidence in what we hope for and assurance about what we do not see" (Hebrews 11:1, New International Version (NIV)). As we can see, faith for Paul the Apostle appears on the one hand, as a pre-knowledge, of what there is not yet, but will exist, and on the other, it contains not only the ground for hope but also the confidence in its implementation. Consequently, faith immanently contains confidence, which is entrenched in hope as a way of endowing the reality of what is expected.

In the Holy Scripture, we can find numerous examples of spiritual and psychotherapeutic possibilities of faith, which in various life vicissitudes become the basis for life choices. In the texts of the Old and New Testaments, due to faith, disbelief is overcome, doubt turns into confidence, and fear disappears. Faith is not permanent, it can be acquired, strengthened, or it can be lost, weakened. Having passed through temptation (trial), faith is intensified; it becomes strong, unshakable, or grows poorer, fades away, and collapses. In general, the effectiveness of faith is verified by deeds, certain actions.

What good is it, my brothers and sisters, if someone claims to have faith

but has no deeds? Can such faith save them? Suppose a brother or a sister

is without clothes and daily food. If one of you says to them, "Go in peace; 
keep warm and well-fed", but does nothing about their physical needs, what good is it? In the same way, faith by itself, if it is not accompanied by action, is dead. (James 2:14-17, New International Version (NIV))

Therefore, faith is directly related to actions which are its effective expression. So, faith contributes to deeds, and deeds, in turn, consolidate it, induce to action, and thereby open the way for human perfection. In general, Christianity offers the consideration of faith in an existentialanthropological sense: as the basis for worldview and spiritual guidance, as an existential, thanks to which a person self-actualizes and realizes its life-meaning potential. By affirming the existence of the sphere of the Divine, the phenomenon of faith thereby legitimizes the transcendental level of being, its irrational possibilities. Relationships of a person with God are formed on the basis of dialogue, thanks to which it becomes possible not only "Self" to go beyond ontological conditionality, but also the individual being acquires new qualitative characteristics. Consequently, religious faith is an experience of meeting human and divine. Such a meeting is characterized by an irrational background, often not subject to verification, and is always an extremely deeply personal, existential event.

The event is the place of a rupture, in which the history changes its meaning, - suddenly opening into a still unexplored window; the event breaks steadiness, destroys visible stability and correctness; it can be as a breakthrough into the future or, conversely, as an invasion of the past, that is denied or suppressed. In the event, you can see the "miracle", the birth of a new truth, at the same time unique and universal, which raises us to the highest point of our existence, or it is possible to see a destructive or traumatic factor. (Fedorova, 2019, p. 40)

Hence, religious faith, as an existential event, expands the space of personality, changes a person. For us, the most complete is the understanding of the religious faith, in which the interiorization and exteriorization of moral values and spiritual elements of culture occur in the lifecreativity of personality. In this context, its meaningful core is its value-meaning content, which combines moral and ethical, intellectual (cognitive) and aesthetic principles. In general, the moral and ethical principle, which serves as an indicator, determines the fullness of social and individual being is a priority in the structural hierarchy of religious faith. Existential experience of faith leads to personal maturity and associated with its acceptance of fate difficulties. Thus, the existential experience of faith must be understood not only as of the horizontal combination of its components but also as a projection into the future, as a projection of the path-search, of travel. 
Thereby, a kind of principle of constant openness is authorized for the affirmation of the absolutely valuable. In this context, faith, on the one hand, justifies a person's aspiration to an infinite future, and on the other hand, gives axiological and spiritual coordinates, which are fixed in the moral ideal. The life of each person moves in the context of the opposition "finitenessinfinity". Therefore, it becomes problematic in the course of an infinite series of questions. The questions, bringing a person out of the state of the given, introduce him into the context of lifemeaning questions, where the bridges of "Self" and "Other" are combined, "drawing" the unique human world. This inclusion, the communion of a person with the Eternal, only confirms the incompleteness of his path-search-journey.

Faith is the basis of human spirituality, his attitudes and the existential foundations of being. The well-known Ukrainian philosopher Serhii Borysovych Krymskyi analyses spirituality, endowing it with the status of a principle, thanks to which a self-construction of a person happens, "building" its core of values, moral attitudes, and priorities.

Spirituality is the ability to transfer the Universum of external being to the inner universe of a personality on an ethical basis, the ability to create that inner world, thanks to which a person's self-identity is realized, his freedom from cruel dependence on situations that are constantly changing. Spirituality, in the end, leads to a kind of meaningful cosmology, combining the image of the world according to the moral law of the personality. (Krymskyi, 1992, p. 23)

Therefore, spirituality is the factor by which egocentrism is overcome; it is the factor by which going beyond personal is possible when the impossible becomes possible. Due to spirituality, it is possible to find the meaning of life, and during periods of crisis and catastrophic eras, through colossal spiritual efforts, it ensures moral survival. Usually, a special place among everyday situations takes boundary, crisis, unique situations when a person feels keenly all the precariousness, the riskiness of his existence, or, in conversely, the need of his place in life. Most clearly "the code of faith" is revealed in boundary situations in which a person, making a breakthrough beyond his own "Self", opens up a completely different dimension of being. We fully agree with the opinion of the Ukrainian philosopher Denys Predko:

It is well-known when life itself falls under the "pressure" of problemati-

zation, a person is forced to "plunge" into comprehending the deep, inti-

mate meanings of life. Actually, he rises to a higher existential level of

comprehension. At the same time, his existentials acquire a personalistic 
colouring, where everything that is purely human is experienced in relation

to God. In this relation, the attitude towards life becomes not the concern

for life, but something above it, which is beyond its limits - its "transcend-

ence" as an ideal that exceeds the limits of life. (Predko, 2018, p. 117)

It is through religious faith that boundary experiences, which are identified as mystical, transcendental, are accompanied by a state of delight, bliss, a sense of fullness, happiness. Incidentally, such states are often associated with the creative processes of the personality or with a change in its spirituality. So, "Faith seems to move mountains in the sense that religion is associated with positive health outcomes" (Hvidt, Hvidtjørn, Christensen, Nielsen, \& Søndergaard, 2017, p. 294).

Therefore, in philosophical and religious discourse, religious faith is characterized by the following features: firstly, faith as a special kind of pre-knowledge, which unfolds in the system of human cognitive abilities; secondly, the status of faith is formed in the context of the assertion of confidence as a moral imperative of a man, that is an important condition of human existence and affirmation; thirdly, faith problematizes and dynamizes the life world in all its diversity, acts as an important ethical value that influences the self-transformation of man in the process of learning, educating the state of God-relation; fourthly, religious faith is based on dogmas and being realized within the limits of authority, nevertheless unites the finite and the infinite, the human and the Divine; fifthly, faith is a complex phenomenon, the components of which are both elements of existence and the elements of the personal.

Through centuries of history, Ukrainians have created a certain way of thinking, feeling, and behaviour, the components of which are the faith that distinguishes them from other nations. Let us pay attention to the characteristics of faith as a factor in the formation of Ukrainian religious consciousness. The well-known historian, psychologist, and sociologist Volodymyr Yaniv (1966) drew attention to geopolitical factors that appeared "on the verge of two worlds" (p. 181) as boundary situations, and they ensured the formation of a kind of Ukrainian faith algorithm. It was the type of faith that was subjected to constant existential tension. The peasantry as a feature was inherent in such type of faith as a kind of feeling the nature, "empathy" and listening to it. It is a living organism that has been going through life for centuries. Such type of faith also possesses a love for the land, that nourishes and inspires both strength and focus on literature and art, in which the spirit of Ukrainian religiosity was most vividly felt. The domination of the emotional and feeling elements over the rational led to the creation of a kind of Ukrainian sensuality. Introvertism as a constant approbation of faith and individualism are components of this type of faith (Yaniv, 1966). Consequently, it was these factors that formed the Ukrainian religious faith, which was archetypally transmitted from generation to generation, creating a living chain of the spiritual axis. However, faith attitudes, arising in the early stages of an ethnos formation, underwent a transformation during a long historical genesis. Despite the historical progress, a certain invariant has been preserved, which reflected common cultural, religious and ethical factors. Through to that, it was possible to preserve national identity, manage to carry it through all the "small Apocalypses" and, finally, to keep and increase what is called the "spirit of the nation", the "soul of the nation". 
Thus, religious faith is the phenomenon by which not only a person finds certain meanings, but also makes certain their ethnic characteristics. This, in fact, the integrative quality, that concerns the sphere of life-meaning values that determine the content, quality and direction of human existence. However, a sense of integrity, fullness can be rare, instant, but at the same time permanently direct individual life. The spiritual experience of faith is the experience of human existence, the experience of "completeness of personality", where one must not only live but also comprehend, create not only oneself in the process of this comprehension but also the world of Other.

The Ukrainian philosopher Hryhórii Skovoroda, along with faith, singled out such lifemeaning orientations as Hope and Love. It is religious faith that sets the projective model of human development, the horizons of his capabilities. Hope paves the way for faith and asserts everything purely human in the realm of experience of the divine. Hope is the feeling that keeps a person afloat. Faith and Hope bring the human heart to the haven of love. Love is the greatest of all virtues. It gives everyone a foundation, creates everything and preserves. "It is fire invisible ... " (Skovoroda, 1994, p. 149).

Faith, Hope, Love are those spiritual and moral virtues that form and contribute to the second birth of a man. Faith ensures a movement towards God and a meeting with Him, acts as a certain guideline of the aspirations and hopes of a person that he is trying to realize. Hope, as the possibility of impossible, strengthens faith, provides a link between the present and the future, and brings them closer. Faith and Hope find their presence in Love, which, by uniting them together and, thus, combining God and a person, promotes dialogue. Some kind of "expectation" happens before the encounter between human and divine when faith only begins to pave its way for realization and hope, entrenching it in projectivity, activates the anticipation of co-presence. Apart from that, love, overcoming the "state of expectation", makes the situational moment of the meeting possible, giving a person the potential of relation to God. How is this possible? It is about single chain - Faith, Hope and Love that can be represented as a "field" (sphere, space, or state), which is distinguished by a certain cumulative spiritual effect. Thus, by a high concentration of all spiritual, intellectual and moral forces, being in tension, in a state of intense perception, a person must "bring" Faith to Hope and Love - and only on this basis adequate conclusions can be drawn.

The life of Hryhórii Skovoroda was constant as travel to himself and faith as a search-finding of God in him. In the process of mystical union with God, a person "resurrects", as if he is being worshiped, reaches the highest bliss and happiness. Such extraordinary movements of the soul activate the emotional and volitional efforts of a person and contribute to his spiritual transformation. It was precisely such an afterlight that $\mathrm{H}$. Skovoroda had experienced. This existential experience served as a basis for clarifying life-worth values for him, and he tried to convey them to others. Such a way of achieving spiritual awakening helps to overcome the hardships of life and anxiety, allows a person to rise above the routine and join the world of the Absolute. However, Skovoroda was an opponent of the fanatical faith, in which the emotional component dominates rational thinking. In order to avoid this, it is necessary to form critical thinking that becomes possible thanks to the philosophical culture of thinking.

This seems in considerable tension, however, with faith-based knowledge -

particularly as that is conceived in Alvin Plantinga's well-known work 


\begin{abstract}
"Warranted Christian Belief". For while there he maintains that faith is a means of knowing religious subject matter, he is also candid that faithbased belief is produced in one by the Holy Spirit in a way that can seem to openly flout the ability constraint on knowledge. (Shaw, 2019, p. 17)
\end{abstract}

It is only partially possible to agree with the reflections of Shaw since religious faith synthesizes not only the cognitive component but also the emotional and volitional component.

Thus, in the process of understanding of religious faith, a kind of dialogue is developing, which is interrogative in nature. A person, being in a certain state of mind and overcoming the boundaries of his own "Self", carries out a projective goal-setting of what excites or embarrasses him. Then, while maintaining the tension of this interrogative attitude and holding the state of mind, the person tries to integrate these processes for striving towards the divine realm, while maintaining spiritual openness and waiting for an answer. Religious faith indicates the orientation of the consciousness of one who turns to God, of one who prays, expresses this orientation in the worldview model, which opens up a whole range of possibilities. In this context, we can recall the bright symbol of communion with God as the meeting of man with God - the fresco of Michelangelo, which emphasizes the main thing in this meeting - the space "between" Adam and God. Such a meeting is carried out as a dialogue in which each moves towards the other, and, in fact, the meeting takes place "between" the participants in the dialogue. Consequently, faith dialogue takes place in the "request-response" plane, which facilitates synergy. Such synergism forms a functional interconnected unity, which defines the meaning of human life, those promising possibilities for the study of faith-dialogue as the quintessence of a person's spiritual potential, where it becomes God-related.

\title{
Originality
}

The author has proved that religious faith, which is a projective model of a person, turns out to be one of the possible ways to solve its existential problems, as it concerns not only the nature of the essential characteristics and properties of the Divine itself but also the ultimate foundations of a man in all its uniqueness and specificity of his being.

\section{Conclusions}

Religious faith, acting as a factor in human activity, builds its value-worldview model of the world. It "deals" with the ultimate problems of human existence, since it is of exceptional importance in solving life-meaning issues of human existence. The existential experience of the believer acquires the status of an event that opens up a field of new possibilities, a new spiritual experience. The accumulative effect of such experience forms the spiritual and value priorities of human existence, sets certain coordinates of his vital activity, due to which he selfdetermines, being in dialogue with the Absolute. Religious faith, unfolding as a permanent process of "search and finding" opens the "code" of transcendence, a new level of relations of the Human and Divine. 


\section{REFERENCES}

Dollahite, D. C., Marks, L. D., Babcock, K. P., Barrow, B. H., \& Rose, A. H. (2019). Beyond Religious Rigidities: Religious Firmness and Religious Flexibility as Complementary Loyalties in Faith Transmission. Religions, 10(2). doi: https://doi.org/10.3390/rel10020111 (in English)

Fedorova, M. (2019). Sobytie: Sovremennye podkhody k formirovaniyu ponyatiya. Voprosy filosofii, 6, 40-49. doi: https://doi.org/10.31857/S004287440005332-0 (in Russian)

Hvidt, N. C., Hvidtjørn, D., Christensen, K., Nielsen, J. B., \& Søndergaard, J. (2017). Faith Moves MountainsMountains Move Faith: Two Opposite Epidemiological Forces in Research on Religion and Health. Journal of Religion and Health, 56(1), 294-304. doi: https://doi.org/10.1007/s10943-016-0300-1 (in English)

Krymskyi, S. B. (1992). Kontury dukhovnosti: Novye konteksty identifikatsii. Voprosy filosofii, 12, $21-28$. (in Russian)

Moskalets, V., \& Oliinyk, A. (2018). Relihiina vira yak antysuitsydalnyi chynnyk. Psykholohichni vymiry kultury, ekonomiky, upravlinnia: Naukovyi zhurnal, 12, 58-75. (in Ukrainian)

Predko, D. (2018). Relihiini pochuttia: Sutnist ta osoblyvosti proiavu: Monohrafiia. Kyiv: VADEKS. (in Ukrainian)

Shaw, K. J. (2019). Faith as extended knowledge. Religious Studies, 55(1), 17-35. doi: https://doi.org/ 10.1017/S0034412517000336 (in English)

Skovoroda, H. (1994). Vstupni dveri do khrystyianskoi dobronravnosti. In N. Ishyna \& N. Kravchenko (Eds.), Tvory: U 2 tomakh (Vol. 1, pp. 140-150). Kyiv: Oberehy. (in Ukrainian)

Yaniv, V. (1966). Relihiinist ukraintsia z etnopsykholohichnoho pohliadu. In V. Yaniv (Ed.), Relihiia $v$ zhytti ukrainskoho narodu (Vol. 181, pp. 179-203). Miunkhen, Rym, Paryzh. (in Ukrainian)

\section{LIST OF REFERENCE LINKS}

Dollahite, D. C. Beyond Religious Rigidities: Religious Firmness and Religious Flexibility as Complementary Loyalties in Faith Transmission / D. C. Dollahite, L. D. Marks, K. P. Babcock, B. H. Barrow, A. H. Rose // Religions. - 2019. - Vol. 10, Iss. 2. - 18 p. doi: https://doi.org/10.3390/rel10020111

Федорова, М. М. Событие: современные подходы к формированию понятия / М. М. Федорова // Вопросы философии. - 2019. - № 6. - C. 40-49. doi: https://doi.org/10.31857/S004287440005332-0

Hvidt, N. C. Faith moves mountains-mountains move faith: two opposite epidemiological forces in research on religion and health / N. C. Hvidt, D. Hvidtjørn, K. Christensen, J. B. Nielsen, J. Søndergaard // Journal of Religion and Health. - 2017. - Vol. 56, Iss. 1. - P. 294-304. doi: https://doi.org/10.1007/s10943016-0300-1

Крымский, С. Б. Контуры духовности: новые контексты идентификации / С. Б. Крымский // Вопросы философии. - 1992. - № 12. - С. 21-28.

Москалець, В. Релігійна віра як антисуїцидальний чинник / В. Москалець, А. Олійник // Психологічні виміри культури, економіки, управління : наук. журн. - 2018. - Т. 12. - С. 58-75.

Предко, Д. С. Релігійні почуття: сутність та особливості прояву : монографія / Д. С. Предко. - Київ : ВАДЕКС, 2018. - $156 \mathrm{c}$.

Shaw, K. J. Faith as extended knowledge / K. J. Shaw // Religious Studies. - 2019. - Vol. 55, Iss. 1. - P. 17-35. doi: https://doi.org/10.1017/S0034412517000336

Сковорода, Г. Вступні двері до християнської добронравності / Г. Сковорода // Твори : у 2 т. / ред. Н. Ішина, Н. Кравченко. - Київ, 1994. - Т. 1 : Поезії. Байки. Трактати. Діалоги. - С. 140-150.

Янів, В. Релігійність українця з етнопсихологічного погляду / В. Янів // Релігія в житті українського народу. - Мюнхен ; Рим ; Париж, 1966. - Т. 181. - С. 179-203.

\section{О. І. ПРЕДКО ${ }^{1 *}$}

\footnotetext{
${ }^{1 *}$ Київський національний університет імені Тараса Шевченка (Київ, Україна), ел. пошта olenapredko@knu.ua, ORCID 0000-0002-9908-7788
}

\section{РЕЛІГІЙНА ВІРА: ЕКЗИСТЕНЦІЙНО-АНТРОПОЛОГІЧНІ СМИСЛИ}


Мета. Дослідження спрямовано на розкриття сутнісних особливостей релігійної віри як екзистенційноперсоналістичної моделі формування людини, іiі світоглядних орієнтирів та діяльності, що передбачає послідовне розв'язання таких задач: а) акцентувати на різноманітні підходи до осмислення феномену "релігійна віра" (як проблемі принципової відкритості, незавершеності людини, як проблемі стосунків "Я-Інший", як проблемі синтезу людського та божественного тощо); б) розкрити духовні можливості релігійної віри, іiї особливості в пограничних ситуаціях. Теоретичний базис. Автор виходить із недостатнього осмислення релігійної віри як впевненості в невидимому. Релігійна віра виступає тим екзистенціалом, завдяки якому людина долає суперечності між скінченністю та нескінченністю, тим конструктом людського духу, який уможливлює іiї вихід в царину трансцендентного. В цьому контексті релігійна віра є своєрідним критерієм "наростання" людського в людині, критерієм іiі духовності та гуманності. Релігійна віра, являючись складовою буття людини, надає йому ірраціональних вимірів, уможливлює неможливе. Екзистенційний потенціал релігійної віри слугує тією "точкою опори" людини, завдяки якій вона самоактуалізується, самоздійснюється й формує певну світоглядну модель. Наукова новизна. Автором доведено, що релігійна віра, в якій віддзеркалюються світоглядні орієнтири людини, виявляється одним із принципів ії самовивищення, способу вирішення екзистенційних проблем. Причому в ній відображаються, з одного боку, сутнісні характеристики, властивості самого Божества, а з іншого - граничні можливості й неможливості людини у всьому розмаїтті унікальності та специфічності ії буття. Висновки. Релігійна віра, виступаючи чинником активності людини, вибудовує їі ціннісно-світоглядну модель світу. Вона "опікується" фатальними проблемами людського буття, так як має виняткове значення при вирішенні сенсожиттєвих питань людського існування. Екзистенційний досвід віруючого набуває статусу події, що відкриває поле нових можливостей, нового духовного досвіду. Акумулятивний ефект даного досвіду формує духовно-ціннісні пріоритети людського буття, задає певні координати життєдіяльності людини, завдяки чому вона самовизначається, знаходячись у діалогічному спілкуванні з Абсолютом. Релігійна віра, розгортаючись як постійний процес "пошукзнаходження", відкриває код трансцендентності, нові грані стосунків царини Людського та Божественного.

Ключові слова: релігійна віра; екзистенційно-вірувальний досвід; діалог; духовність; погранична ситуація; Віра-Надія-Любов

\section{Е. И. ПРЕДКО ${ }^{1 *}$}

${ }^{1 *}$ Киевский национальный университет имени Тараса Шевченко (Киев, Украина), эл. почта olenapredko@knu.ua, ORCID 0000-0002-9908-7788

\section{РЕЛИГИОЗНАЯ ВЕРА: ЭКЗИСТЕНЦИАЛЬНО- АНТРОПОЛОГИЧЕСКИЕ СМЫСЛЫ}

Цель. Исследование направлено на раскрытие сущностных особенностей религиозной веры как экзистенциально-персоналистической модели формирования человека, его мировоззренческих ориентиров и деятельности, что предусматривает последовательное решение следующих задач: а) акцент на различные подходы к осмыслению феномена "религиозная вера" (как проблеме принципиальной открытости, незавершенности человека, как проблемы отношений "Я-Другой", как проблеме синтеза человеческого и божественного и т.п.); б) раскрыть духовные возможности религиозной веры, ее особенности в пограничных ситуациях. Теоретический базис. Автор исходит из недостаточного осмысления религиозной веры как уверенности в невидимом. Религиозная вера выступает тем экзистенциалом, благодаря которому человек преодолевает противоречия между конечностью и бесконечностью, тем конструктом человеческого духа, который обеспечивает его выход в сферу трансцендентного. В этом контексте религиозная вера является своеобразным критерием "нарастания" человеческого в человеке, критерием его духовности и гуманности. Религиозная вера, являясь составной бытия человека, придает ему иррациональных измерений, способствует невозможному. Экзистенциальный потенциал религиозной веры служит той "точкой опоры" человека, благодаря которой он самоактуализируется, самоосуществляется и формирует определенную мировоззренческую модель. Научная новизна. Автором доказано, что религиозная вера, в которой отражаются мировоззренческие ориентиры человека, оказывается одним из принципов ее самовозвышения, способом решения экзистенциальных проблем. Причем в ней отражаются, с одной стороны, сущностные характеристики, свойства самого Божества, а с другой - предельные возможности и невозможности человека во всем разно- 
образии уникальности и специфичности его бытия. Выводы. Религиозная вера, выступая фактором активности человека, выстраивает ее ценностно-мировоззренческую модель мира. Она "занимается" фатальными проблемами человеческого бытия, так как имеет исключительное значение при решении смысложизненных вопросов человеческого существования. Экзистенциальный опыт верующего приобретает статус события, открывает поле новых возможностей, нового духовного опыта. Аккумулятивный эффект данного опыта формирует духовно-ценностные приоритеты человеческого бытия, задает определенные координаты его жизнедеятельности человека, благодаря чему он самоопределяется, находясь в диалогическом общении с Абсолютом. Религиозная вера, разворачиваясь как постоянный процес "поиск-нахождение", открывает код трансцендентности, новые грани отношений сферы Человеческого и Божественного.

Ключевые слова: религиозная вера; экзистенциально-веровальный опыт; диалог; духовность; пограничная ситуация; Вера-Надежда-Любовь

Received: 16.07.2019

Accepted: 22.11.2019 